\title{
Acute nutrient treatment causes alterations in intra-follicular antioxidation and AKT signaling
}

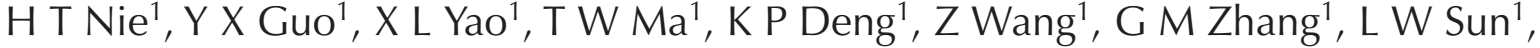 \\ Z Y Wang ${ }^{1}$, H C Wang ${ }^{2}$ and F Wang ${ }^{1}$ \\ ${ }^{1}$ Jiangsu Engineering Technology Research Center of Meat Sheep and Goat Industry, College of Animal Science and \\ Technology, Nanjing Agricultural University, Nanjing City, JiangSu Province, People's Republic of China and ${ }^{2}$ Animal \\ Husbandry and Veterinary Station of GuanNan, LianYunGang City, JiangSu Province, People's Republic of China
}

Correspondence should be addressed to F Wang; Email: caeet@njau.edu.cn

\begin{abstract}
This study aimed to determine if short-term nutrient alteration affects (1) ovarian morphology, (2) plasma and ovarian antioxidant capability and (3) cell apoptosis and AKT signaling within the ovary. After estrus synchronization, 24 Hu sheep were assigned to three groups based on the nutrient requirement recommended for maintenance $(M): 1 \times M(C o n t r o l), 1.5 \times M(S)$ and $0.5 \times M(R)$ during days 7-14 of their estrous cycle. The results indicated that undernourishment significantly increased the counts and volume of follicles $<2.5 \mathrm{~mm}$ and decreased the counts and volume of follicles $\geq 2.5 \mathrm{~mm}(P<0.05)$. Feed restriction altered the plasma and follicular redox balance within follicles $\geq 2.5 \mathrm{~mm}$ by inhibiting total antioxidant capacity, increasing malondialdehyde concentration $(P<0.05)$ and reducing the mRNA expression levels of superoxide dismutase $2(S O D 2)$ and glutathione peroxidase $(G S H-P X)$, as well as the activities of total SOD and GSH-PX. Feed restriction also attenuated B-cell lymphoma-2 (BCL2) but enhanced Bcl-2-associated $X$ protein $(B A X)$ and $B A X / B C L 2$ transcription and translation levels in granulosa cells $(P<0.05)$. Uniform staining intensities of AKT and P-AKT-Ser473 were observed in each follicle stage, whereas weaker P-AKT-Thr308 staining in the antral follicle than in the pre-antral follicle suggested possible involvement of P-AKT-Thr308 during the beginning of follicle development. P-AKT-Ser473 levels in follicles $\geq 2.5 \mathrm{~mm}$ was significantly reduced in the $\mathrm{R}$ group $(P<0.05)$. The results presented in this study demonstrate that suppressed folliculogenesis caused by feed restriction might be associated with attenuated AKT signaling, reduced follicular antioxidant capacity and enhanced granulosa cells apoptosis.

Reproduction (2018) 155 37-49
\end{abstract}

\section{Introduction}

Folliculogenesis is a nutritionally sensitive process that is readily influenced by altered nutrient intake (Scaramuzzi et al. 2006). Short-term increases in nutrient flux, including feed intake supplementation (Ying et al. 2011), glucose infusion (Gallet et al. 2011, Scaramuzzi et al. 2015), lupin grain supplementation (Somchit et al. 2007) and co-treatment with nutritional supplementation (Muñoz-Gutiérrez et al. 2002, 2004) during the luteal phase, can stimulate folliculogenesis in sheep. In contrast, ewe fasting in the luteal phase of their estrous cycle shows reduced ovulation rates (Killeen 1982). Although metabolites and hormones directly signal follicles to regulate folliculogenesis by altering nutrient flux, their underlying physiological mechanisms remain unclear.

Physiological changes during folliculogenesis are selective pressures imposed on the antral follicles because one will become dominant and the others remain subordinate and are destined for atresia (Zhang et al. 2014). A majority of developing ovarian follicles in both avian and mammalian species are eliminated on a continuous basis throughout the female reproductive performance via follicle atresia (Kaipia \& Hsueh 1997). Apoptosis evasion by granulosa cells may be particularly critical to follicular development (Matsuda-Minehata et al. 2005). Oxidative stress (OS) plays a role in granulosa cells apoptosis during follicular atresia (Tilly \& Tilly 1995). Accumulating pieces of evidence show that reactive oxygen species (ROS) provide vital signals for initiation of follicle atresia, triggered by various external stimuli such as pesticides, environmental chemicals, ionizing radiation and gonadotropin withdrawal (Hoyer et al. 2001, Tsaiturton \& Luderer 2006). Under conditions of nutrition limitation, gluconeogenesis and fat mobilization are enhanced, mitochondrial energy metabolism changes, the oxidant/ antioxidant balance changes and the body may suffer from stress to oxygen (Bruynsteen et al. 2014). However, the role of ROS in short-term/acute effect of nutrition on follicular development has received limited attention, and to our knowledge, little information is available on 
intra-follicular redox balance alternation responses to short-term nutritional treatment during the luteal phase.

AKT is activated by phosphyrylation of upstream kinases, including phosphoinositide dependent kinase-1/2, phosphorylate threonine 308 and/or serine 473.. AKT activation also increases the phosphorylation of downstream targets and consequently decreases apoptosis (Cheng et al. 1997). AKT signaling is an important cell survival pathway associated with increased expression of anti-apoptotic genes in apoptosis-resistant cells (Johnson \& Boise 1999). AKT is further activated by hormonal responses under specific nutrient conditions and is known as a negative apoptosis regulator in diverse cell lines (Ding et al. 2000, Wang et al. 2000), including granulosa cells (Asselin et al. 2001). In other cell types, Akt kinase is an upstream apoptosis regulator activated by increased ROS levels. It is also well described that AKT activation is associated with enhanced ROS levels (Lahair et al. 2006), whereas AKT depletion leads to diminished ROS generation and promotes stress defenses; thus, these processes inhibit $\mathrm{H}_{2} \mathrm{O}_{2}$ or Ras activation-induced senescence of embryonic cells (Nogueira et al. 2008). These combined results indicate that AKT signaling is sensitive to disturbed ROS and triggers apoptosis progression. However, the role of the AKT pathway in the response of ovine granulosa cells to external factors such as change in short-term dietary levels in the luteal phase is yet to be explored, and the relationships between this pathway and oxidative damage are yet to be examined in detail.

In the present study, we aimed to investigate the effect of short-term supplementation or restriction of feed intake in the luteal phase on the estrous cycle, ovarian morphology, plasma and ovarian antioxidant capacity, transcription levels of genes encoding glucose transporters and steroidogenic enzymes, immunohistochemical localization and levels of AKT protein and phosphorylated AKT protein in ovarian tissues and granulosa cells, respectively, and mRNA and protein expression levels of apoptosis-related proteins.

\section{Materials and methods \\ Experiment design}

The experiment was conducted at HaiLun Sheep Industry Co. Ltd. (Taizhou, Jiangsu, China; longitude: 120.24, latitude: $32.44^{\circ}$ ), using 24 multiparous Hu sheep (average body weight: $43.69 \pm 1.27 \mathrm{~kg}$ ) of similar age (average age: $2-3$ years). The animal protocols used in this study were in accordance with procedures approved by the Guide for the Care and Use of Laboratory Animals prepared by the Ethics Committee of Nanjing Agricultural University (SYXK 2011-0036). Humane animal care and handling procedures were followed throughout the experiment.

All the ewes were synchronized using intra-vaginal progestagen sponges $(30 \mathrm{mg}$; Ningbo Sansheng pharmaceutical Co., LTD, Zhejiang, China) for 12 days. Following implant removal, prostaglandin F2 $\alpha$ (PGF2 $\alpha, 20 \mathrm{mg}$; Ningbo Sansheng Co., LTD) was injected intra-muscularly for initiating follicular development. Estrous behavior was monitored using vasectomized rams following the second day of pessary removal; the end of estrous cycle was considered to be day 0 of the next estrous cycle. During the next 7 days (from day 0 to day 6 of the estrous cycle), all ewes were confined to individual pens and were offered a total mixed ration (Supplementary Table 1, see section on Supplementary Data given at the end of this article) based on the feeding standards of China (NY/T816-2004, China) recommended for maintenance requirement (M). From day 7 to day 14 of the estrous cycle, all ewes were randomly assigned to $1 \times \mathrm{M}$ (Control; $n=8$; average dry matter intake of $1.04 \mathrm{~kg} /$ day $), 0.5 \times \mathrm{M}(\mathrm{R} ; n=8$; average dry matter intake of $0.52 \mathrm{~kg} /$ day $)$ and $1.5 \times \mathrm{M}(\mathrm{S} ; n=8$; average dry matter intake of $1.56 \mathrm{~kg} /$ day) groups, with water provided to the sheep ad libitum. All sheep received a maintenance diet on other days of the estrous cycle. Individual estrous behaviors were monitored from day 15 of the estrous cycle, and the relative day of estrus initiation was recorded to calculate the estrous cycle. Individual animals were simultaneously killed for follicle collection on the second day of estrous behavior initiation monitored using vasectomized rams. The schematic representation of the experimental design is shown in Supplementary Material_Fig. 1.

\section{Blood sample collection}

Blood samples $(10 \mathrm{~mL})$ were obtained to measure plasma concentrations of glucose and insulin. Samples were collected every $6 \mathrm{~h}$ from 24 to $114 \mathrm{~h}$ relative to the start of dietary intake treatment, from day 6 to day 11 of the estrous cycle. These samples were collected in EDTA $(4.45 \pm 0.85 \mu \mathrm{mol}$ per $\mathrm{mL}$ blood sample) tubes (U-Real Medical Technology Co., Ltd, Zhejiang, China). Samples were maintained on ice and separated by $10 \mathrm{~min}$ of centrifugation at $1207 \mathrm{~g}$ at $4^{\circ} \mathrm{C}$. The resultant plasma samples were stored at $-20^{\circ} \mathrm{C}$ until analysis.

\section{Ovary dissection and morphology}

The ovaries were collected within 5 min of death, immediately placed into a thermos flask with sterilized saline $\left(30-35^{\circ} \mathrm{C}\right.$, with $100 \mathrm{IU} / \mathrm{mL}$ penicillin and $100 \mathrm{mg} / \mathrm{mL}$ streptomycin). The ovarian connective tissues and attached oviducts were removed after washing five times with sterilized saline. All visible follicles $\geq 1.0 \mathrm{~mm}$ in diameter were dissected free from the ovarian stroma using fine scissors and fine-toothed dissecting forceps and placed in Dulbecco's PBS (D-PBS, $10 \mathrm{~mL}, 30-35^{\circ} \mathrm{C}$; Invitrogen) in a sterile plastic Petri dish. Follicular diameter was measured to the nearest millimeter and follicles were grouped based on diameters $<2.5 \mathrm{~mm}$ $(1-2.0 \mathrm{~mm}, 2-2.5 \mathrm{~mm})$ and $\geq 2.5 \mathrm{~mm}(2.5-3.5 \mathrm{~mm}, 3.5-5 \mathrm{~mm})$, using a graph paper grid placed under the dish.

\section{Granulosa cell isolation and follicular fluid sample processing}

The dissected follicles were kept in D-PBS until collection of granulosa cells was completed. First, the GC layer was gently 
scraped from the interior surface of the follicle wall into a sterile plastic Petri dish containing D-PBS using a platinum loop. The D-PBS containing the GC pellets and follicular fluid were then transferred to another $1.5-\mathrm{mL}$ microtube and centrifuged at $4{ }^{\circ} \mathrm{C}$ and $1207 \mathrm{~g}$. for $10 \mathrm{~min}$. Following centrifugation, the follicular fluids were separated and diluted to a final volume of $1 \mathrm{~mL}$ with PBS, and stored at $-20^{\circ} \mathrm{C}$ for further analysis. The remaining GC pellets were re-suspended and centrifuged at $300 \mathrm{~g}$ after $5 \mathrm{~min}$ incubation at $37^{\circ} \mathrm{C}$ in red blood cell lysis buffer (thrice the volume of the GC pellets). After the supernatant was discarded, cell pellets were re-suspended and pipetted up and down to verify that the red blood cells had completely disappeared, followed by snap-freezing in liquid nitrogen for further analysis.

\section{Plasma and follicular fluid glucose and insulin assay}

Insulin concentration was analyzed through an equilibriumcompetitive radioimmunoassay (RIA) using a commercial RIA Kit (Beijing Furui Bio-Tech Co., Ltd, Beijing, China). According to the manufacturer, the sensitivity of the assay was $2 \mu \mathrm{IU} / \mathrm{mL}$. The intra- and inter-assay coefficients of variation (CVs) were $<10 \%$ and $<15 \%$, respectively. Glucose concentrations were analyzed by the glucose hexokinase (GOD-PAP) method described by Ying and coworkers, and the intra- and inter-assay CVs were $<3 \%$ and $<5 \%$, respectively; the limit of sensitivity for the glucose assay was $0.5 \mu \mathrm{mol} / \mathrm{mL}$ (Ying et al. 2011).

\section{Detection of T-AOC, GSH-PX, SOD and MDA concentrations in plasma and follicular fluid}

The activity of total superoxide dismutase (T-SOD, $\mathrm{kU} / \mathrm{mL}$ ) was determined using a commercial detection kit (Cat No: S0101, Beyotime Biotechnology, Nantong, China) according to the procedure described by Chen and coworkers (Chen et al. 2016). Glutathione peroxidase (GSH-PX, nmol/mL) concentration was determined using the method described by Yakubu and coworkers (Yakubu et al. 2011). Before measurement, the samples were supplemented with an equal volume of $5 \%(\mathrm{v} / \mathrm{v})$ metaphosphoric acid and centrifuged at $3000 \mathrm{~g}$ for $10 \mathrm{~min}$ at $4{ }^{\circ} \mathrm{C}$. Malondialdehyde (MDA, $\mathrm{nmol} / \mathrm{mL}$ ) activity measurement was performed according to the protocol described by Ohkawa and coworkers (Ohkawa et al. 1979). The TBA working solution was prepared by mixing $0.2 \mathrm{~mL}$ SDS (8.1\%), $1.5 \mathrm{~mL}$ acetic acid (20\%, pH 3.5) and $1.5 \mathrm{~mL} \mathrm{TBA}(0.8 \%)$, and $0.2 \mathrm{~mL}$ of each thawed sample was then mixed with this $3.2 \mathrm{~mL}$ working TBA working solution and $0.8 \mathrm{~mL}$ distilled water. The mixture was incubated in a boiling water bath for $1 \mathrm{~h}$ and then cooled on ice. After cooling, the mixture was mixed with $5 \mathrm{~mL} \mathrm{~N}$-butanolpyridine $(15: 1 \mathrm{v} / \mathrm{v})$ and $1 \mathrm{~mL}$ distilled water, and centrifuged at $250 \mathrm{~g}$ for $5 \mathrm{~min}$. The absorbance of the upper butanol phase was read at $520 \mathrm{~nm}$ against a blank. Total antioxidant capacity activity (T-AOC, U/mL) was examined using a commercial kit (Cat No: S0119; Beyotime Biotechnology), according to the manufacturer's instructions.

\section{Immunohistochemistry}

Formalin-fixed, paraffin-embedded tissue sections were cut to a thickness of $6 \mu \mathrm{m}$. Sections were deparaffinized in xylene, followed by rehydration in a series of graded ethanol concentrations. The tissue epitopes were activated by exposing to a citrate antigen retrieval solution (Beyotime Biotechnology) in a microwave at $100^{\circ} \mathrm{C}$ for $15 \mathrm{~min}$. After cooling to room temperature, the sections were treated with $3 \%(\mathrm{v} / \mathrm{v}) \mathrm{H}_{2} \mathrm{O}_{2}$ in methanol for $10 \mathrm{~min}$ to inactivate the endogenous peroxidase. Following three washes with $0.1 \%$ $(\mathrm{v} / \mathrm{v})$ Triton X-100/PBS (PBST), the sections were blocked in an immunostaining blocking buffer (Beyotime Biotechnology) for $1 \mathrm{~h}$ and then incubated overnight at $4{ }^{\circ} \mathrm{C}$ with primary antibodies against AKT, P-AKT-Thr308 and P-AKT-Ser473, diluted 1:200 in PBST with $2 \%(\mathrm{w} / \mathrm{v})$ bovine serum albumin (BSA), in a humidified chamber. After incubation, the specimens were washed twice in PBS and then incubated at room temperature for $10 \mathrm{~min}$ with a biotin-conjugated secondary antibody (A0208, Beyotime Biotechnology) at a dilution of $1: 100$ at $37^{\circ} \mathrm{C}$ for $1 \mathrm{~h}$. Before coloration with the substrate chromogen 3,3'-diaminobenzidine, the secondary antibody was sufficiently washed off. The sections were then counterstained with hematoxylin and mounted with cover slips. Negative control sections were processed simultaneously as described earlier, but without adding an antibody. The primary antibodies were replaced with PBS in the negative control experiments.

\section{RT-PCR}

For each ewe, the collected GC samples from the same-sized follicles $(<2.5 \mathrm{~mm}$ or $\geq 2.5 \mathrm{~mm}$ in diameter $)$ were mixed. Total RNA was isolated from follicles of different sizes using RNAprep Pure Tissue Kit (Tiangen Biotechnology Co. Ltd, Beijing, China), according to the protocols provided by the manufacturer. The concentration and quality were determined by a NanoDrop 2000 Spectrophotometer (Thermo Fisher Scientific). The complementary DNA (cDNA) was synthesized using PrimeScript RT Master Mix (Takara Biotechnology) with $1 \mu \mathrm{g}$ total RNA as the template, following the manufacturer's protocol. cDNA samples were stored at $-20^{\circ} \mathrm{C}$ until realtime PCR amplification. First, $1 \mu \mathrm{g}$ total RNA was treated with gDNA Eraser for $2 \mathrm{~min}$ at $42^{\circ} \mathrm{C}$ for genomic DNA removal, and then reverse-transcribed using Master Mix at $37^{\circ} \mathrm{C}$ for $15 \mathrm{~min}$, followed by $85^{\circ} \mathrm{C}$ for $5 \mathrm{~s}$. RT-PCR was performed on a Step One Plus Real-Time PCR System (Applied BioSystems) using FastStart SYBR Green Master mix (Roche). The sequences and GenBank accession numbers of the primer sets used for amplifying the target genes, (1) apoptosis-related genes: $\mathrm{Bcl}$-2-associated $\mathrm{X}$ protein $(B A X)$ and B-cell lymphoma-2 $(B C L 2) ;(2)$ antioxidant capacity-related genes: Superoxide dismutase 1, 2 and 3 (SOD1, 2 and 3); (3) glucose transporterrelated genes: Solute carrier family 2 facilitated members 1 , 3, 4 and 8 (SLC2A1, 3, 4 and 8); (4) steroidogenic enzyme genes: Cytochrome P450scc (CYP11A1), Cytochrome p450 (CYP17A1) and Cytochrome p450 aromatase (CYP19A1), are presented in Table 1. Each 20- $\mu$ L PCR reaction was prepared as follows: $2 \mu \mathrm{L}$ cDNA, $10 \mu \mathrm{L}$ SYBR green ER Master mix, $6.8 \mu \mathrm{L}$ nuclease-free water and $0.6 \mu \mathrm{L}$ each of the forward and reverse primers $(10 \mu \mathrm{mol})$. The reactions were performed with the following conditions: initial denaturation at $50^{\circ} \mathrm{C}$ for $2 \mathrm{~min}$ and $95^{\circ} \mathrm{C}$ for $10 \mathrm{~min}$, followed by 40 cycles (denaturation at $95^{\circ} \mathrm{C}$ for $15 \mathrm{~s}$, annealing at $60^{\circ} \mathrm{C}$ for $30 \mathrm{~s}$ and extension at $72^{\circ} \mathrm{C}$ for 
Table 1 Details of primer sequences, expected product sizes and accession numbers of genes used for RT-PCR.

\begin{tabular}{|c|c|c|c|c|}
\hline \multirow[b]{2}{*}{ Genes } & \multirow[b]{2}{*}{ Accession number } & \multicolumn{2}{|c|}{ Primer sequences $\left(5^{\prime}-3^{\prime}\right)$} & \multirow[b]{2}{*}{ Production size $(b p)$} \\
\hline & & Forward & Reverse & \\
\hline$S L C 2 A 1$ & U89029.1 & TCGTCGTCGGCATCCTCATC & TCCACCACAAACAGCGAAACG & 496 \\
\hline$S L C 2 A 3$ & NM_001009770.1 & AAATTAGGGCCATGGGGACC & GAGAGTACCAAAGGCACCCC & 482 \\
\hline SLC2A4 & AB005283.1 & TGGAGCAGGAAGTGAAACCC & GTCACACGAGGGGAATGAGG & 249 \\
\hline$S L C 2 A 8$ & AF495799.1 & ATGGAGCCTGCCAATACCAA & TCTCAGACATGAGGAGCCACG & 118 \\
\hline$B C L 2$ & DQ152929.1 & CGCATCGTGGCCTTCTTT & CGGTTCAGGTACTCGGTCATC & 113 \\
\hline$B A X$ & AF163774.1 & CGAGTGGCGGCTGAAAT & GGTCTGCCATGTGGGTGTC & 238 \\
\hline SOD1 & NM_001145185 & TGGGACATGGTCTGAGTCCT & CTTGAGAGAATCAAAATTCAGGCA & 278 \\
\hline SOD2 & XM_013966636.1 & GTGAACAACCTCAACGTCGC & GCGTCССTGСТССТTATTGA & 300 \\
\hline SOD3 & XM_012179753.1 & CACGCCAAGGTGACAGAGAT & TCCAGTAGGGAGAGATGCGG & 179 \\
\hline$G S H-P X$ & XM_005695962.2 & ACATTGAAACССТGСТGTCC & TCATGAGGAGCTGTGGTCTG & 216 \\
\hline CYP11A1 & NM_001093789 & GTTTCGCTTTGCCTTTGAGTC & ACAGTTCTGGAGGGAGGTTGA & 158 \\
\hline CYP17A1 & NM_001009483 & CTTACCATTGACAAAGGCACAGAC & GCTTAATGATGGCGAGATGAGTTG & 144 \\
\hline CYP19A1 & AJ012153 & TCGTCСTGGTCACССТTCTG & СGGTСTСTGGTСTСGTCTGG & 115 \\
\hline GAPDH & NM_001034034.1 & CGACTTCAACAGCGACACTCAC & СССТGTTGCTGTAGCCGAATTC & 119 \\
\hline
\end{tabular}

$30 \mathrm{~s})$, and a dissociation step consisting of $95^{\circ} \mathrm{C}$ for $15 \mathrm{~s}, 60^{\circ} \mathrm{C}$ for $15 \mathrm{~s}$ and $95^{\circ} \mathrm{C}$ for $15 \mathrm{~s}$. At the end of the PCR reactions, melt curve analyses were performed for all genes. Results were normalized to the house-keeping gene GAPDH. Gene expression levels were quantified using the $\Delta \Delta \mathrm{Ct}$ method. For each comparison, the average gene expression level of granulosa cells within follicles $\geq 2.5 \mathrm{~mm}$ from the Control group was set at 1.00 .

\section{Western blot}

Total proteins were extracted from granulosa cells using radioimmunoprecipitation assay buffer (Beyotime Biotechnology) and were quantified using the bicinchoninic acid assay kit (Dingguo, Nanjing, China). Protein samples $(\geq 1.5 \mu \mathrm{g} / \mu \mathrm{L})$ were diluted in gel-loading buffer, boiled for $10 \mathrm{~min}$, followed by $12 \%$ SDS-polyacrylamide gel electrophoresis and then electrotransferred to polyvinylidene fluoride membranes (Millipore) at $200 \mathrm{~mA}$ for $2 \mathrm{~h}$. The membrane was incubated with Tris-buffered saline containing $0.05 \%$ Tween 20 (TBST) with 5\% (w/v) BSA for $1 \mathrm{~h}$ to block non-specific binding, followed by overnight incubation at $4^{\circ} \mathrm{C}$ with primary antibodies to target the proteins AKT, P-AKTThr308, P-AKT-Ser473, BAX and BCL2 (detailed in Table 2). After several washes with TBST, the proteins were incubated with secondary antibodies (goat anti-rabbit IgG and goat antimouse IgG secondary antibody) for $1 \mathrm{~h}$ at room temperature, according to the species of origin of the primary antibodies. Immunoreactive bands were visualized using Image Quant LAS 4000 (Fujifilm, Tokyo, Japan) with the ECL detection reagent. Band intensities were estimated by densitometry and normalized to GAPDH. Densitometric analysis of the bands was performed using Image J software (Wayne Rasband, Maryland, USA); protein expression levels were quantified and reported as arbitrary units relative to a set value of 1 for samples from follicles $\geq 2.5 \mathrm{~mm}$ of the Control group (means \pm S.E.M.).

\section{Statistical analysis}

Statistical analyses were performed using the SPSS statistical software (version 16.0; SPSS). The data were analyzed for normality using the Kolmogorov-Smirnov goodness-of-fit test. Data that did not follow a normal distribution were analyzed using an equivalent non-parametric test. Follicle counts and the estrous cycle were tested by the $\chi^{2}$ test using Fisher's exact probability test. For each feeding level treatment, the data on follicles with two different diameters were analyzed using independent sample $t$-tests. Data of plasma antioxidant capacity and follicle volume were analyzed for feeding level treatment effects using one-way ANOVA. Post hoc differences between treatment groups were further examined using Tukey's test. Two-way ANOVA with follicle size as one variable and nutrient as another variable was performed to study the follicle size and nutritional treatment effects. For all tests, differences with a $P$-value $<0.05$ were considered as statistically significant.

\section{Results}

\section{Estrous cycles and ovarian morphology}

Table 3 demonstrates that the mean estrous cycle $(19.25 \pm 0.48$ days) of the $R$ group was significantly delayed compared with that of the $S$ group $(16.75 \pm 0.48$ days) and the Control group (17.75 \pm 0.63 days; $P<0.05$, respectively).

Ewes from each group experienced at least two corpora luteal $(\mathrm{CL})$ phases, and this observation confirmed that these ewes were in the luteal phase of the estrous cycle. The feed treatment did not significantly affect the mean number of $\mathrm{CL}$ phases in $<5 \mathrm{~mm}$ or $\geq 5 \mathrm{~mm}$ size classes $(P>0.05)$. The mean counts of follicles classified as 1.0-2.0, 2.0-2.5, 2.5-3.5 and 3.5-5.0 mm were similar among different groups $(P>0.05)$. The ewes under feed restriction treatment possessed numerous follicles with diameters $<2.5 \mathrm{~mm}$ and few follicles with diameters $\geq 2.5 \mathrm{~mm}(P<0.05)$. The feed treatment did not affect the mean volume of follicles in 1-2, 2.0-2.5, 2.5-3.5 and 3.5-5.0 mm size classes. Conversely, the feed treatment significantly influenced the mean volume of follicles in $<2.5$ and $\geq 2.5 \mathrm{~mm}$ size classes ( $P<0.05$, respectively). The ewes on feed restriction treatment showed a high 
Table 2 Details of primary and secondary antibodies used for immunohistochemistry (IHC) and Western blot (WB) in this experiment.

\begin{tabular}{lllll}
\hline Antibodies & Species & Source (Cat No.) & Dilution in IHC & Dilution in WB \\
\hline AKT & Rabbit polyclonal & Biobyt Ltd, California, United States (Orb235003) & 0.18056 & 0.5625 \\
P-AKT-Ser473 & Rabbit polyclonal & Biobyt Ltd, California, United States (Orb 11293) & 0.18056 & 0.38889 \\
P-AKT-Thr308 & Rabbit polyclonal & Biobyt Ltd, California, United States (Orb14786) & 0.18056 & 0.25 \\
BAX & Mouse polyclonal & Santa Cruz Ltd, California, USA (SC526) & - & 0.18056 \\
BCL2 & Mouse polyclonal & Boster Ltd, Wuhan, China (BA0412) & - & 0.18056 \\
GAPDH & Mouse polyclonal & Beyotime Ltd, Haimen, China (AF0006) & - & 0.5625 \\
Goat anti-Rabbit IgG & Goat polyclonal & Beyotime Biotechnology, Nantong, China (A0208) & 0.11111 & 0.73611 \\
Goat anti-Mouse IgG & Goat polyclonal & Beyotime Biotechnology, Nantong, China (A0216) & 0.11111 & 0.73611 \\
\hline
\end{tabular}

$(-)$, absent.

volume of follicles with diameters $<2.5 \mathrm{~mm}$ and a low volume of follicles with diameters $\geq 2.5 \mathrm{~mm}(P<0.05)$.

\section{Glucose and insulin concentration of plasma and follicular fluid}

As illustrated in Fig. $1 \mathrm{~A}$ and $\mathrm{B}$, the mean glucose concentrations of the $\mathrm{R}$ group were similar on days $6,7,8$ and 11 , but were elevated on days 9 and 10 $(P<0.05)$; the $S$ group ewes had higher plasma glucose concentration than that in the Control and $R$ groups on days 7 and $11(P<0.05)$, whereas similar concentrations were observed on days 8,9 and 10 among different feeding treatments $(P>0.05)$. Insulin concentrations on days 9 and 11 were higher in $S$ group ewes than in $R$ and Control group ewes $(P<0.05)$. In the $S$ group, the mean insulin concentrations were similar on days 6,8 and 10 , and were lower than those on days 7, 9 and $11(P<0.05)$.

The independent effects of treatment, plasma collection period and interactions in terms of individual days are shown in Table 4. There was a significant effect of feeding levels $(P<0.05)$ but not of sampling times $(P>0.05)$ on the plasma glucose and insulin concentration, and the feeding levels by sampling times interaction were insignificant $(P>0.05)$. The mean glucose and insulin concentrations in samples collected from day 7 to day 11 of the estrous cycle, corresponding to $0 \mathrm{~h}$ to $114 \mathrm{~h}$ relative to nutrient treatment, were significantly lower in the $\mathrm{R}$ group than that in the Control and $\mathrm{S}$ groups $(P<0.05)$. Additionally, the average concentration of plasma glucose and insulin was similar across day 7 through day $11(P>0.05)$.

Table 5 shows that follicular fluid insulin and glucose concentrations varied with feeding levels along with follicle sizes. The mean concentrations of intra-follicular glucose were reduced in follicles with diameters $<2.5 \mathrm{~mm}$ than that in follicles with diameters $\geq 2.5 \mathrm{~mm} \quad(P<0.05)$; however, similar glucose concentrations between follicles $<2.5 \mathrm{~mm}$ and follicles $\geq 2.5 \mathrm{~mm} \quad(P>0.05)$ were observed

Table 3 Detected estrous cycles, mean number and calculated volume of different size follicles from ewes under different feed treatments during the luteal phase.

\begin{tabular}{|c|c|c|c|c|c|}
\hline \multirow[b]{2}{*}{ Items } & \multicolumn{3}{|c|}{ Feed treatments ${ }^{1}$} & \multirow[b]{2}{*}{ S.E.M. } & \multirow[b]{2}{*}{$P$-Value } \\
\hline & $\mathrm{R}$ & $\mathrm{S}$ & Control & & \\
\hline Mean estrous cycle (days) & $19.25^{\mathrm{a}}$ & $16.75^{b}$ & $17.75^{\mathrm{b}}$ & 0.48 & $<0.05$ \\
\hline \multicolumn{6}{|c|}{ Mean number of Corpus luteum } \\
\hline$<5 \mathrm{~mm}$ in diameter & 3.67 & 3.26 & 2.82 & 0.53 & NS \\
\hline$\geq 5 \mathrm{~mm}$ in diameter & 0.50 & 0.71 & 0.82 & 0.26 & NS \\
\hline \multicolumn{6}{|c|}{ Mean number of ovarian follicles } \\
\hline $1-2.0 \mathrm{~mm}$ in diameter & 11.75 & 10.25 & 10.25 & 1.11 & NS \\
\hline $2.0-2.5 \mathrm{~mm}$ in diameter & 3.13 & 2.63 & 2.38 & 0.46 & NS \\
\hline $1-2.5 \mathrm{~mm}$ in diameter & $14.88^{\mathrm{a}}$ & $12.96^{\mathrm{b}}$ & $12.54^{\mathrm{b}}$ & 0.71 & $<0.05$ \\
\hline $2.5-3.5 \mathrm{~mm}$ in diameter & 1.13 & 1.63 & 1.38 & 0.34 & NS \\
\hline $3.5-5 \mathrm{~mm}$ in diameter & 0.63 & 1.13 & 1.25 & 0.29 & NS \\
\hline $2.5-5 \mathrm{~mm}$ in diameter & $1.75^{\mathrm{a}}$ & $2.75^{\mathrm{b}}$ & $2.63^{\mathrm{c}}$ & 0.26 & $<0.05$ \\
\hline \multicolumn{6}{|c|}{ Mean volume of ovarian follicles $\left(\mathrm{mm}^{3}\right)^{2}$} \\
\hline $1-2.0 \mathrm{~mm}$ in diameter & 2.47 & 1.86 & 1.82 & 0.35 & NS \\
\hline $2.0-2.5 \mathrm{~mm}$ in diameter & 4.72 & 4.11 & 4.02 & 0.48 & NS \\
\hline $1-2.5 \mathrm{~mm}$ in diameter & $7.19^{\mathrm{a}}$ & $5.97^{\mathrm{b}}$ & $5.84^{\mathrm{b}}$ & 0.39 & $<0.05$ \\
\hline $2.5-3.5 \mathrm{~mm}$ in diameter & 8.21 & 8.97 & 9.14 & 0.58 & NS \\
\hline $3.5-5 \mathrm{~mm}$ in diameter & 21.17 & 25.82 & 24.77 & 2.36 & NS \\
\hline $2.5-5 \mathrm{~mm}$ in diameter & $29.38^{\mathrm{a}}$ & $34.79^{b}$ & $33.91^{\mathrm{b}}$ & 0.96 & $<0.05$ \\
\hline
\end{tabular}

${ }^{1} \mathrm{R}, \mathrm{S}$ and Control indicated that ewes treated with $0.5 \times$ maintenance diet (R group; $n=8$ ), a maintenance diet (Control group; $n=8$ ) or $1.5 \times$ maintenance diet (S group; $n=8$ ) from day 7 to day 14 of the luteal phases, the same as below; ${ }^{2}$ the mean volume of ovarian follicles was calculated using the formula: Follicles volume $\left(\mathrm{mm}^{3}\right)=0.52 \times\left(\right.$ diameter $\left.(\mathrm{mm})^{2.7}\right)$; the different superscript letters indicate a significant difference $(P<0.05)$ 


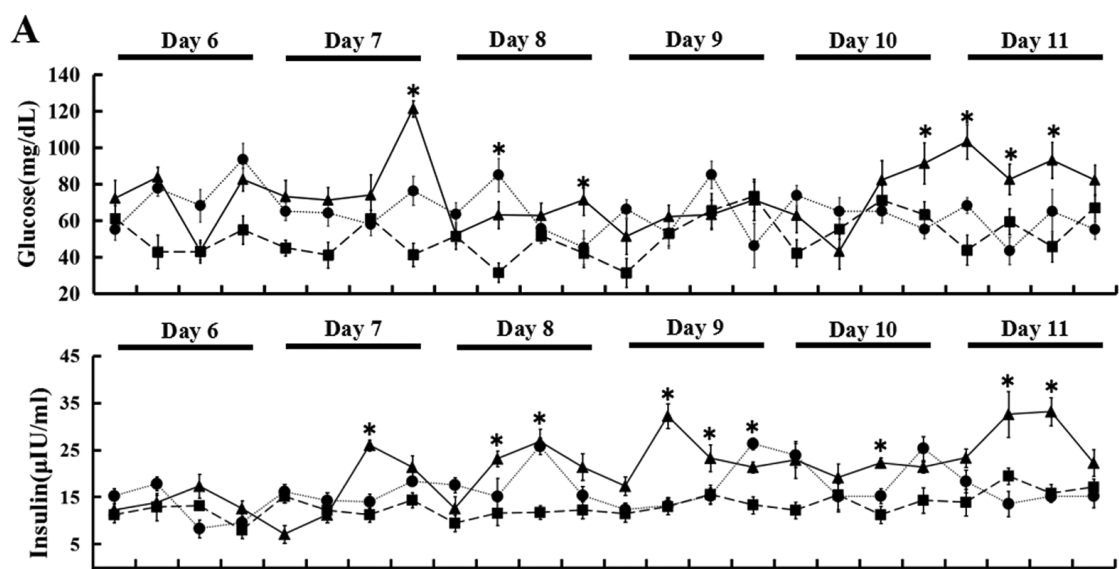

B

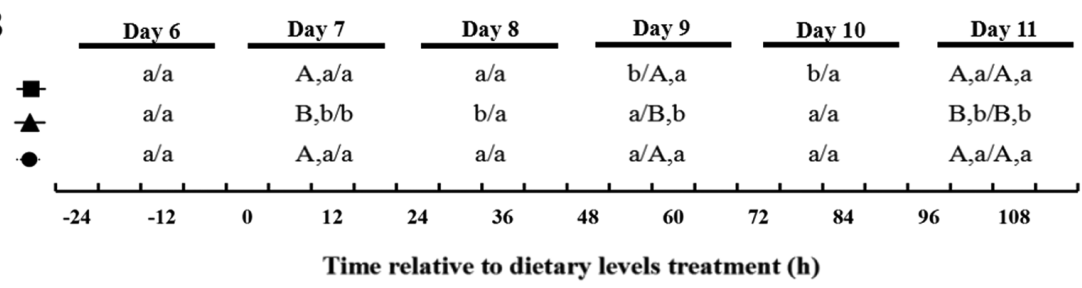

- Restricted feed group

- Control group
Figure 1 (A) Plasma glucose and insulin profile concentrations before and after the nutrient treatments, corresponding from day 6 to day 11 relative to the estrus cycle. ${ }^{a}$ The significant independent effect of feeding levels $(P<0.05)$; the Control group ewes were fed a maintenance $(M)$ diet (Control; $\square$ ), the restricted feed group ewes were fed at $0.5 \times \mathrm{M}$ requirement diet $(R ; \mathbf{O})$ and the supplemented group ewes were fed at $1.5 \times$ maintenance diet (S; $\mathbf{\Delta})$. (B) The effects of feeding levels and collecting time on plasma glucose and insulin concentration. The significant differences are indicated with capital letters in the same column (various feeding levels treatment in the same day) and small letters in the same row (various days in the same feeding level); different letters (Glucose/Insulin) mean significant difference $(P<0.05)$, the same letter or no letter means no significant difference $(P>0.05)$. only in the $\mathrm{R}$ group ewes. Additionally, the mean concentrations of intra-follicular insulin were also similar between these follicles of various sizes $(P>0.05)$. In contrast, the insulin concentrations in follicles with diameters $<2.5 \mathrm{~mm}$ in the $\mathrm{R}$ group were higher than those in follicles with diameters $\geq 2.5 \mathrm{~mm}$ $(P<0.05)$.

\section{Antioxidant capacities of plasma, follicular fluid and granulosa cells}

As shown in Table 6, the GSH-Px activity and MDA concentration were increased in the $\mathrm{R}$ group compared with those in the $\mathrm{S}$ and Control groups $(P<0.05)$. Feed restriction significantly decreased the plasma activities of T-SOD and T-AOC in the $\mathrm{R}$ group than those in the $\mathrm{S}$ and Control groups $(P<0.05$, respectively; Table 4). Additionally, nutrient treatment and follicle size significantly affected the T-AOC and T-SOD activities in follicular fluid $(P<0.05)$, and the mean activities of T-AOC and T-SOD in follicles
$<2.5 \mathrm{~mm}$ were significantly greater than those in follicles $\geq 2.5 \mathrm{~mm}$. Conversely, the T-AOC and T-SOD activities were low in follicles $\geq 2.5 \mathrm{~mm}$ from the underfed group than those in follicles of the same size from the $\mathrm{S}$ and Control groups $(P<0.05)$. The mean concentrations of GSH-Px and MDA were similar between follicles $<2.5 \mathrm{~mm}$ and follicles $\geq 2.5 \mathrm{~mm}$ $(P>0.05)$, but the mean GSH-Px decreased and the mean MDA concentrations increased in follicles $\geq 2.5 \mathrm{~mm}$ from the $\mathrm{R}$ group $(P<0.05)$.

As illustrated in Fig. 2, follicle size $(P>0.05)$ or treatment $(P>0.05)$ did not affect the SOD1 and SOD3 mRNA expression levels in granulosa cells. However, the SOD2 mRNA expression levels of granulosa cells within follicles $\geq 2.5 \mathrm{~mm}$ from the $\mathrm{R}$ group were significantly lower than those from the $\mathrm{S}$ and Control groups $(P<0.05)$. The GSH-PX mRNA expression was lower $(P<0.05)$ within follicles $\geq 2.5 \mathrm{~mm}$ in the $\mathrm{R}$ group than those from the $S$ and Control groups, and this expression was also less than that in the follicles $<2.5 \mathrm{~mm}$ from the same nutrient treatment group $(P<0.05)$.

Table 4 Plasma glucose and insulin concentration from ewes under different feed treatments during the luteal phase.

\begin{tabular}{|c|c|c|c|c|c|c|c|c|c|c|c|c|c|}
\hline \multirow[b]{2}{*}{ Items } & \multicolumn{3}{|c|}{ Feeding levels } & \multirow[b]{2}{*}{ S.E.M. } & \multicolumn{5}{|c|}{ Sampling times } & \multirow[b]{2}{*}{ S.E.M. } & \multicolumn{3}{|c|}{$P$-Value } \\
\hline & $\mathrm{R}$ & $\mathrm{S}$ & Control & & Day 7 & Day 8 & Day 9 & Day 10 & Day 11 & & $\mathrm{FL}$ & ST & $\mathrm{FL} \times \mathrm{ST}$ \\
\hline Plasma glucose $(\mathrm{mg} / \mathrm{mL})$ & $51.78^{a}$ & $73.33^{b}$ & $64.62^{b}$ & 8.17 & 64.56 & 76.28 & 70.19 & 73.35 & 77.05 & 7.85 & $<0.05$ & NS & NS \\
\hline Plasma insulin $(\mu \mathrm{IU} / \mathrm{mL})$ & $13.14^{\mathrm{a}}$ & $20.67^{b}$ & $16.50^{\mathrm{ab}}$ & 2.28 & 16.31 & 17.28 & 19.07 & 20.35 & 19.98 & 2.21 & $<0.05$ & NS & NS \\
\hline
\end{tabular}

a,b Means different in plasma parameter compared between feeding levels and sampling times $(P<0.05)$.

FL, the independent effect of feeding levels; FL $\times$ ST, the interaction effect of feeding levels and sampling times; ST, the independent effect of sampling times. 
Table 5 Follicular fluid glucose and insulin concentration from ewes under different feed treatments during the luteal phase.

\begin{tabular}{cccccccc}
\hline & \multicolumn{3}{c}{ Follicular glucose $(\mathrm{mg} / \mathrm{mL})$} & & \multicolumn{3}{c}{ Follicular insulin $(\mu \mathrm{lU} / \mathrm{mL})$} \\
\cline { 2 - 3 } \cline { 6 - 7 } & $\mathrm{R}$ & $\mathrm{S}$ & Control & & $\mathrm{R}$ & \multicolumn{3}{c}{$\mathrm{S}$} & Control \\
\hline Follicular diameter $(\mathrm{mm})$ & & & & & \\
$<2.5$ & 32.31 & $31.14^{\mathrm{a}}$ & 32.07 & & $213.56^{\mathrm{a}, \mathrm{x}}$ & $159.67 \mathrm{y}$ & $152.78^{\mathrm{y}}$ \\
$\geq 2.5$ & $32.67^{\mathrm{x}}$ & $43.00^{\mathrm{b}, \mathrm{y}}$ & $42.74^{\mathrm{y}}$ & & $151.15^{\mathrm{b}}$ & 162.78 & 149.65 \\
S.E.M. & 3.14 & 3.16 & 3.24 & & 14.29 & 13.26 & 13.87 \\
$P$-Value & $\mathrm{NS}$ & $<0.05$ & $<0.05$ & & $<0.05$ & $\mathrm{NS}$ & $\mathrm{NS}$ \\
\hline
\end{tabular}

Significant difference $(P<0.05)$.

${ }^{a, b}$ Compared dietary levels within same follicle size; ${ }^{x, y}$ compared

follicle sizes within the same dietary level. Different letters indicate ' $\mathrm{a}$ '.

\section{Quantitative PCR for genes encoding glucose transporters and steroidogenic enzymes within granulosa cells}

In Fig. 3A, the transcription levels of $S \angle C 2 A 1, S L C 2 A 3$ and $S L C 2 A 8$ did not differ significantly within granulosa cells across different groups with various dietary intake and follicle sizes. Our results indicated a significant increase in SLC2A4 mRNA abundance of granulosa cells within follicles $\geq 2.5 \mathrm{~mm}$ compared with that in follicles with diameters $<2.5 \mathrm{~mm}$ within the same treatment group $(P<0.05$, respectively). The expression of SLC2A4 in granulosa cells within follicles $<2.5 \mathrm{~mm}$ was significantly increased with increasing feed intake $(P<0.05)$. As shown in Fig. 3B, the mRNA abundance of CYP17A1 within granulosa cells from follicles $\geq 2.5 \mathrm{~mm}$ was significantly increased $(P<0.05)$ in the $\mathrm{R}$ group than that in the $S$ and Control groups. Additionally, undernutrition significantly increased the CYP19A1 expression within granulosa cells from follicles $>2.5 \mathrm{~mm}$, whereas the transcription level of CYP11A1 was neither affected by nutritional treatment $(P>0.05)$ nor by follicle size $(P>0.05)$.

\section{Immunolocalization of AKT, P-AKT-Thr308 and P-AKT- Ser473 in ovarian tissues}

The immunoreactivity of AKT, P-AKT-Thr308 and P-AKTSer473 proteins indicated that these target proteins were mainly localized in the cytoplasm of oocytes from the primordial and primary follicle stages (Fig. 4A, D and

Table 6 Plasma antioxidant capacity from ewes under different feed treatments during the luteal phase.

\begin{tabular}{|c|c|c|c|c|c|}
\hline & \multicolumn{3}{|c|}{ Feeding levels } & \multirow[b]{2}{*}{ S.E.M. } & \multirow[b]{2}{*}{$\boldsymbol{P}$} \\
\hline & $\mathrm{R}$ & $\mathrm{S}$ & Control & & \\
\hline Plasma T-AOC (U/mL) & $11.78^{\mathrm{a}}$ & $18.92^{b}$ & $17.87^{\mathrm{b}}$ & 1.06 & $<0.05$ \\
\hline Plasma total SOD (U/mL) & $27.23^{\mathrm{a}}$ & $58.66^{b}$ & $62.27^{b}$ & 3.09 & $<0.05$ \\
\hline Plasma GSH-Px (nmol/mL) & $61.89^{a}$ & $45.23^{b}$ & $44.71^{b}$ & 3.62 & $<0.05$ \\
\hline Plasma MDA (nmol/mL) & $4.28^{\mathrm{a}}$ & $2.21^{b}$ & $2.32^{\mathrm{b}}$ & 0.34 & $<0.05$ \\
\hline
\end{tabular}

www.reproduction-online.org
G); the oocyte cytoplasm and granulosa cells were also positively stained in the pre-antral follicles (Fig. 4B, $\mathrm{E}$ and $\mathrm{H}$ ), and the immunoreactivity of these proteins was also observed in granulosa cells and the thecal cells in antral follicles (Fig. 4C, F and I). No specific immunoreactivity was detected in the negative control (Fig. 4J). A uniform staining intensity of AKT and P-AKTSer473 was observed in granulosa cells from follicle at each growing stage; on the other hand, granulosa cells in pre-antral follicles (Fig. 4E) were shown to express high levels of P-AKT-Thr308 than those in antral follicles (Fig. 4F), showing weak staining.

\section{AKT, P-AKT-Thr308 and P-AKT-Ser473 protein levels within granulosa cells}

As shown in Fig. $5 \mathrm{~A}$ and $\mathrm{B}$, quantification of the signal bands revealed similar levels of AKT and P-AKT-Ser473 in granulosa cells between follicles with various follicle sizes, but p-AKT-Thr308 shows lower expression in granulosa cells from follicles $\geq 2.5 \mathrm{~mm}$ than that in granulosa cells within follicles $<2.5 \mathrm{~mm}$. Additionally, the P-AKT-Ser473 levels normalized to AKT expression in granulosa cells within follicles $\geq 2.5 \mathrm{~mm}$ were significantly lower in the $R$ group than that in the $S$ and Control groups. Conversely, follicle size $(P>0.05)$ or nutrient treatment $(P>0.05)$ did not affect the AKT protein levels within granulosa cells significantly.

\section{Transcription and translation levels of BAX and BCL2 in granulosa cells}

As shown in Fig. 6, compared with those from the S and Control groups, the translation levels of BAX and the $\mathrm{BAX} / \mathrm{BCL} 2$ ratio in granulosa cells within follicles $\geq 2.5 \mathrm{~mm}$ were upregulated $(P<0.05)$, whereas the BCL2 expression was reduced in the $\mathrm{R}$ group (Fig. $6 \mathrm{~A}$ and $\mathrm{B}$ ). These altered expression patterns for BCL2 and BAX, as well as the BAX/BCL2 ratio were also confirmed at the transcription level within granulosa cells $(P<0.05)$.

\section{Discussion}

vInsulin is a nutritional mediator that regulates folliculogenesis (Downs \& Utecht 1999) and acts as a nutritional signal directly at the ovarian level to increase intra-follicular glucose uptake (Muñoz-Gutiérrez et al. 2004). Glucose enters cells via a family of glucose transporters 1, 3, 4 and 8 (Williams et al. 2001). Our present study demonstrated a decreased SLC2A4 mRNA abundance in granulosa cells from follicles $<2.5 \mathrm{~mm}$ of the $\mathrm{R}$ group (Fig. 2), and this finding corresponds to a relatively lower entrance rate of glucose into follicular cells resulting from inhibited feed intake. In our study, feed restriction significantly decreased the mean concentration of plasma glucose and insulin. 

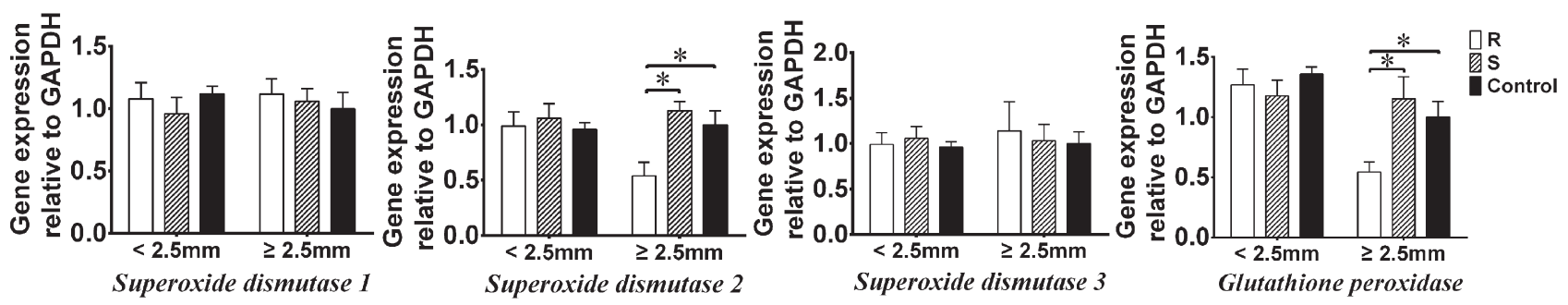

Figure 2 Results of mRNA expression levels of genes, Superoxide dismutase 1, 2 and 3 (SOD1, 2 and 3) and glutathione peroxidase (GSH-PX), responsible for antioxidant capacity of GCs within $<2.5$ and $\geq 2.5 \mathrm{~mm}$ follicles from different feeding levels during day 7 to day 14 of the estrus cycle. The symbol of * indicated the significant difference detected among different feeding levels treatment $(P<0.05)$. Relative mRNA expression levels were quantified and reported as arbitrary units relative to a set value of 1 for samples from $\geq 2.5 \mathrm{~mm}$ follicles of Control group, and the same as below.

However, only in the $\mathrm{R}$ group, the glucose level was not significantly decreased with decreasing follicle size. Additionally, intra-follicular insulin was significantly increased in follicles $<2.5 \mathrm{~mm}$ but was similar among different nutrient treatments in follicles $\geq 2.5 \mathrm{~mm}$ (Table 4). Combining these results, we suggested that the rate of glucose transportation into cells by SLC2A4 was more dependent on the insulin levels than on glucose concentration, and was more reliant on circulating insulin levels than on intra-follicular insulin levels. Additionally, the similar SLC2A expression levels within follicles $\geq 2.5 \mathrm{~mm}$ in different nutrient treatments revealed an environment with equivalent local glucose, and the variation in local glucose-insulin environment among the nutrient treatment groups was diminished in terms of the classification by follicular diameter. We speculated that these phenomena could be attributed to the following: (1) Under negative energy status, the requirements of dominant or subdominant follicles must be satisfied, and the inward transport rates among different dietary levels, especially in follicles $\geq 2.5 \mathrm{~mm}$, remain unchanged; (2) another nutrient sensing and metabolic mechanism likely modifies the energy availability in follicles $\geq 2.5 \mathrm{~mm}$ among different nutrient treatments independent of changes in facilitative glucose transporters; however, these conditions should be tested and verified in further studies.

Our understanding of the important roles of ROS and $O S$ in mammalian female reproduction has been remarkably improved. Endogenous antioxidant enzymes, such as GSH-Px and SOD, can neutralize ROS. As a metabolic product of lipid peroxides (Zhan et al. 2007), MDA is an indicator of ROSinduced OS. In the present research, the plasma concentration of GSH-Px increased to prevent additional generation of lipid peroxide products as the dietary intake level decreased. The increased MDA concentration indicated that OS was also induced by
$A(a)$

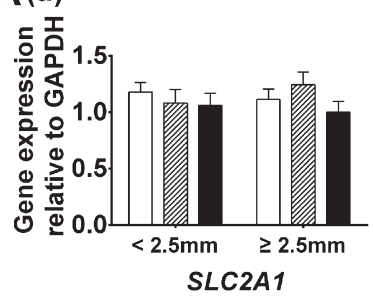

$B$ (a)

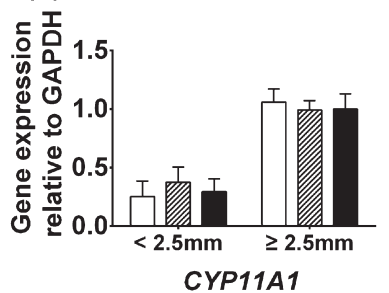

(b)

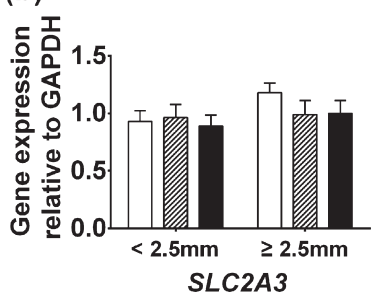

(b)

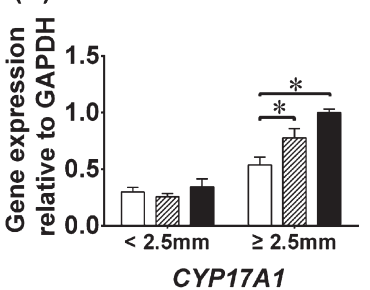

(c)

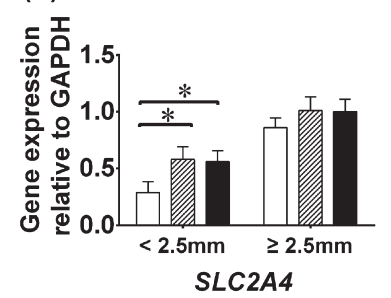

(c)

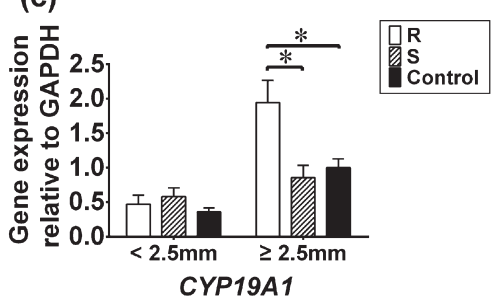

(d)

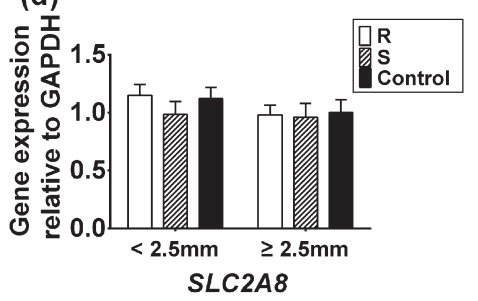

Figure 3 Gene expression in follicles from follicles $<2.5 \mathrm{~mm}$ and $\geq 2.5 \mathrm{~mm}$ in diameter from 3 groups of Hu sheep fed different nutritional diets during day 7 to day 14 of the estrus cycle. (A) Glucose transporter-related genes: Solute carrier family 2 facilitated members $1,3,4$ and 8 (SLC2A 1, 3, 4 and 8); (B) Steroidogenic enzyme genes: Cytochrome P450sCC (CYP11A1), Cytochrome p450 (CYP17A1) and Cytochrome p450 aromatase (CYP19A1). 

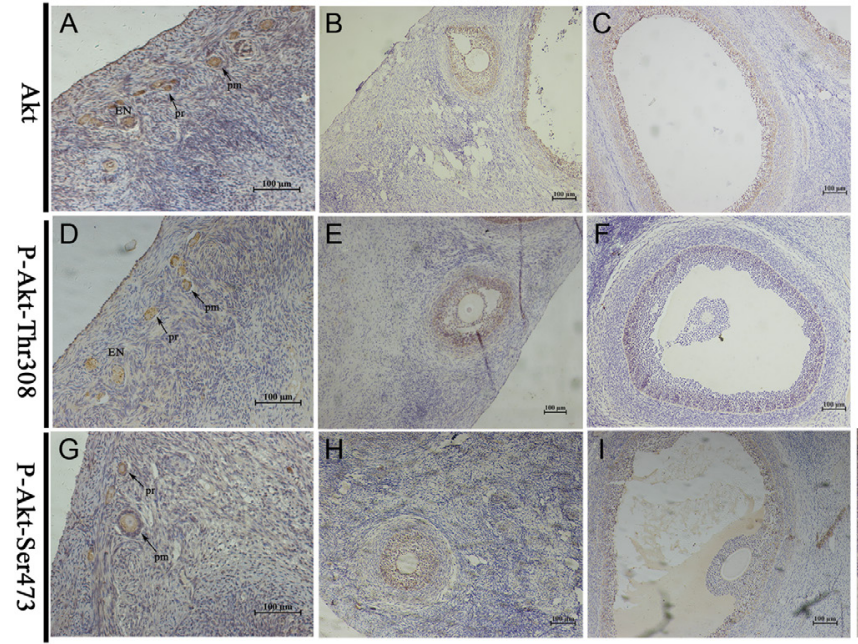

nourishment. This finding is similar to that obtained by Amer and coworkers who found that sheep with a restricted feeding regime demonstrate a significantly increased serum concentration of total cholesterol (TCHO), which acts as an antioxidant for free radical scavenging (Amer et al. 2013). Although TCHO was not determined in this study, nutritionally sensitive $\mathrm{TCHO}$ was previously reported by Ying and coworkers, as they found that plasma $\mathrm{TCHO}$ levels increased following a switch from a normal feed intake to an underfed intake during the luteal phase (Ying et al. 2011). Therefore, short-term starvation in the luteal

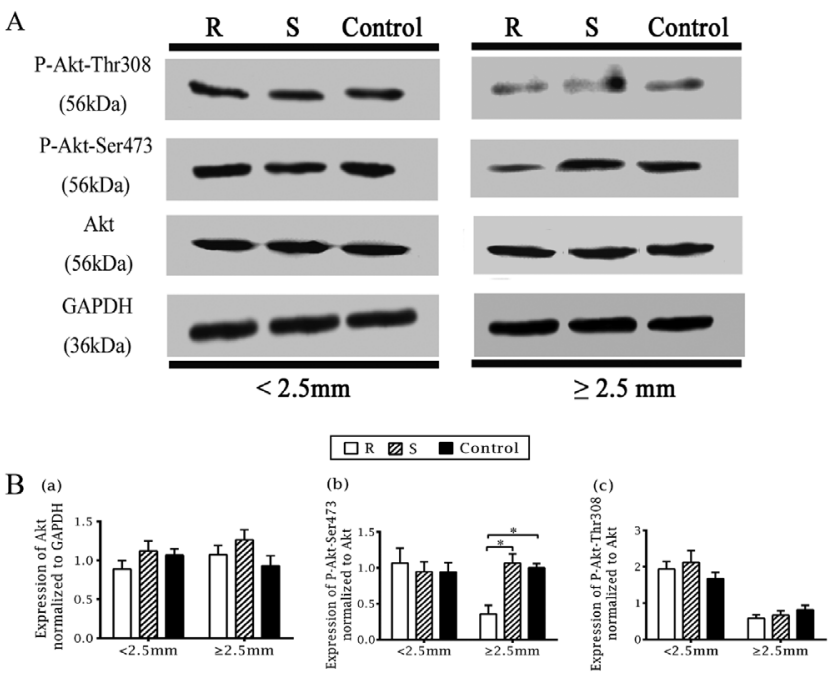

Figure 5 (A) Western blot bands of non-phosphorylated AKT (56 kDa), and ratio of phosphorylated to non-phosphorylated of AKT at threonine $308(56 \mathrm{kDa})$ and Serine $473(56 \mathrm{kDa})$ in GCs from $<2.5$ and $\geq 2.5 \mathrm{~mm}$ follicles of ewes treated with different feeding levels during day 7 to day 14 of the estrus cycle. GAPDH served as an internal control (36 kDa). (B) Relative protein expression levels were quantified and reported as arbitrary units relative to a set value of 1 for samples from $\geq 2.5 \mathrm{~mm}$ follicles of Control group (means \pm S.E.M.), the same as below in the Western blot results analysis.

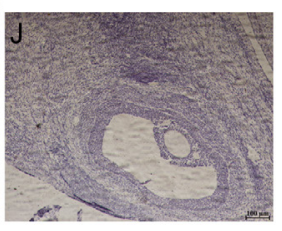

Figure 4 Immunohistochemical localization of AKT (A, B and C), P-AKT-Thr308 (D, E and F), P-AKT-Ser473 (G, H and I) and negative control $(J)$ in ovarian tissues with primordial and primary follicles (A, D and $\mathrm{G}$ ), pre-antral $(\mathrm{B}, \mathrm{E}$ and $\mathrm{H})$ and antral follicles $(\mathrm{C}, \mathrm{F}$ and $\mathrm{I})$. phase of sheep possibly caused an imbalance of prooxidants and antioxidants, and this phenomenon might be involved in the mechanism by which short-term dietary restriction inhibits folliculogenesis.

Three isoforms of enzymatic antioxidant SODs, namely $\mathrm{Cu} / \mathrm{Zn}-\mathrm{SOD}$ (SOD1), Mn-SOD (SOD2) and Fe-SOD (SOD3), exist with varying structures, regulation, localization and functions (Johnson \& Giulivi 2005). We also found that intra-follicular total SOD activity but not mRNA abundance of genes responsible for SOD isoforms appeared to be dependent on follicle size (Fig. 3 and Table 7). This result is similar to observations in the pig model (Basini et al. 2008). The changing pattern of GSH-PX expression within granulosa cells was similar to the intra-follicular GSH-PX activity response to follicle sizes and feed intake treatment, which suggests that follicular granulosa cells are the potential exogenous sources of GSH-Px variations induced by follicle development and nutrient status. In contrast, no change was observed in SOD gene expression levels when the antral follicles increased in size, whereas the total SOD activity in follicles $<2.5 \mathrm{~mm}$ was higher than that in follicles $\geq 2.5 \mathrm{~mm}$. It has been reported that not all follicular compartments exhibit similar changes in SODs (Fattman et al. 2003). Therefore, oocytes and thecal cells, which were not examined in the present study, might show a compartmentalized and varying $S O D$ expression influenced by nutrient status. Further studies should examine follicular variation in the potential dependence of granulosa cells on exogenous sources of antioxidants as well as the degree of OS experienced by follicles. Follicle size and dietary intake did not affect the expression of the selected enzymatic antioxidant SOD isoforms, except for the mRNA levels of SOD2 (Mn-SOD), which is mainly located in the mitochondrial matrix (Yikilmaz et al. 2006). Therefore, we further suggested that the intra-follicular pro-oxidant and antioxidant imbalance caused by undernourishment might be related to mitochondrial dysfunction in 
A

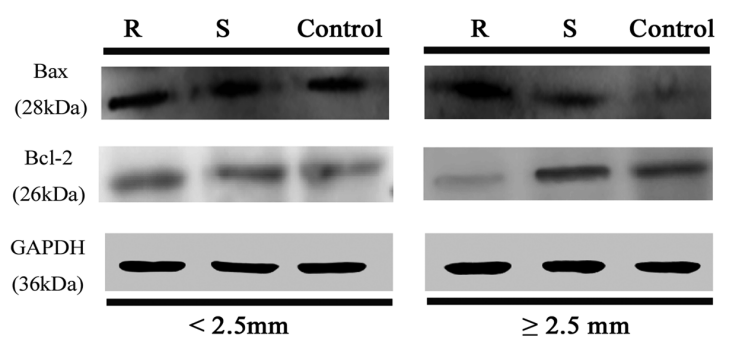

B
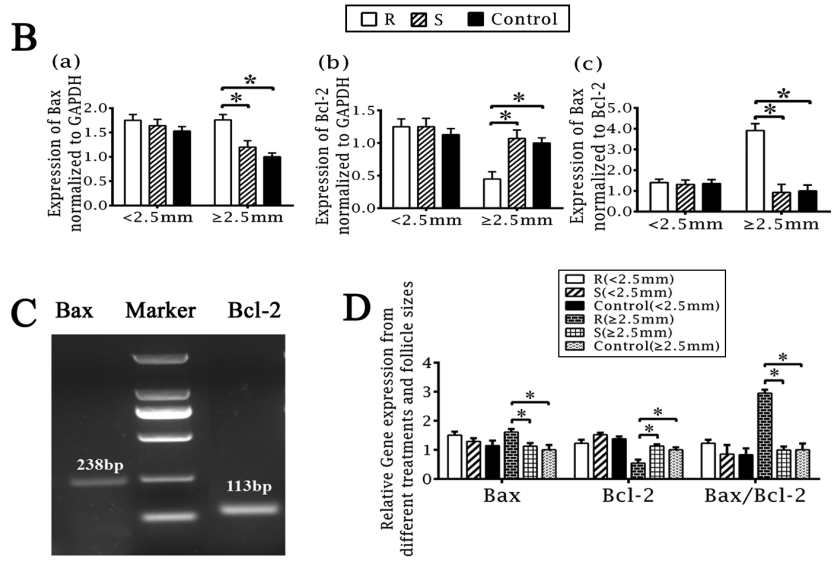

Figure 6 Translation and transcription levels of $B A X, B C L 2$ and $\mathrm{BAX} / \mathrm{BCL} 2$ ratio within GCs from $<2.5$ and $\geq 2.5 \mathrm{~mm}$ follicles from three groups of Hu sheep fed $0.5 \times$ maintenance diet (R group; $n=8$ ), a maintenance diet (Control group; $n=8$ ) or $1.5 \times$ maintenance diet (S group; $n=8$ ) during day 7 to day 14 of the estrus cycle. (A) Immunoblots for BAX (28 kDa), BCL2 (26 kDa) and GAPDH (36 kDa). (B, C and D) Relative protein and mRNA expression levels were quantified and reported as arbitrary units relative to a set value of 1 for samples from $\geq 2.5 \mathrm{~mm}$ follicles of Control group (B and D; means \pm S.E.M.).

granulosa cells, especially those in follicles $>2.5 \mathrm{~mm}$. These results were also similar to those described in an in vivo model of 3-nitropropionic acid-induced ovarian OS in mice. Under this condition, the number of large follicles decreased and the percent of atretic follicles among the large follicles in the ovaries increased; in comparison, these parameters within small-and mediumsized follicles did not change (Zhang et al. 2014).

AKT in the mammalian ovary plays a key role in controlling follicular and oocyte development
(Cecconi et al. 2012). In the porcine ovary, AKT is localized in granulosa cells of primordial follicles and in the basal layers of granulosa cells from pre-antral and antral follicles, but not in atretic follicles or the corpora lutea (Meng et al. 2007). In the human ovary, AKT is expressed in oocytes, granulosa cells and thecal cells of primordial follicles in follicles at each growing stage including in the luteal cells (Goto et al. 2007). In rodents, AKT has been found in both granulosa cells and oocytes (Reddy et al. 2005). Similar to these results, AKT and P-AKT-Thr308/Ser473 proteins were, respectively, detected in the oocyte cytoplasm and in granulosa cells and thecal cells from follicles at each growing stage in the present study. Additionally, uniform staining intensities of AKT and P-AKT-Ser473 were found at each follicle stage, whereas weak staining for P-AKT-Thr308 was observed in the antral follicle compared with that in the pre-antral follicle. Immunohistochemistry for P-AKT-Thr308 in serial sections showed good agreement with western blotting results, which show a greater P-AKT-Thr308 expression in granulosa cells from follicles $\geq 2.5 \mathrm{~mm}$ than that in follicles $<2.5 \mathrm{~mm}$, suggesting that P-AKT-Thr308 levels decreased during the beginning of follicle growth.

Granulosa cell death induced by apoptosis has been demonstrated in mice (Hughes \& Gorospe 1991), cows (Jolly et al. 1994), ewes (Murdoch 1995) and pigs (Sugimoto et al. 1998). During the development of mammalian ovarian follicles, a limited number of follicles are selected for ovulation, whereas the remaining follicles undergo atresia at various developmental stages, especially in the luteal phase; ovarian follicles preferentially undergo atresia (Viñoles Gil 2003). Our results indicated that the transcription and translation levels of $\mathrm{BAX}$ and the BAX/BCL2 ratio were upregulated, but the gene and protein expression levels of BCL2 were significantly reduced in granulosa cells from follicles $\geq 2.5 \mathrm{~mm}$ of the $\mathrm{R}$ group. This finding suggested that the inhibited follicle development caused by feed restriction might be related to the greater number of granulosa cells with triggered apoptosis, which caused ovarian follicular atresia and impaired further developmental capacity. The mechanisms controlling atresia in small and large follicles seem to be independently regulated (Waddington et al. 1985). Small follicles may be inherently less susceptible to normal physiological factors that induce atresia

Table 7 Intra-follicular antioxidant capacity from ewes under different feed treatments (R, S and control) during the luteal phase and presented according to follicle diameter size.

\begin{tabular}{|c|c|c|c|c|c|c|c|c|c|c|c|c|}
\hline & \multicolumn{4}{|c|}{$\mathbf{R}$} & \multicolumn{4}{|c|}{$\mathbf{S}$} & \multicolumn{4}{|c|}{ C } \\
\hline & $<2.5$ & $\geq 2.5$ & S.E.M. & $P$ & $<2.5$ & $\geq 2.5$ & S.E.M. & $P$ & $<2.5$ & $\geq 2.5$ & S.E.M. & $P$ \\
\hline FF T-AOC (U/mL) & $15.66^{\mathrm{a}}$ & $1.08^{b, x}$ & 0.52 & $<0.05$ & $16.28^{\mathrm{a}}$ & $3.21^{b, y}$ & 0.53 & $<0.05$ & $15.78^{\mathrm{a}}$ & $2.95^{\mathrm{b}, \mathrm{y}}$ & 0.37 & $<0.05$ \\
\hline FF total SOD (U/mL) & $31.31^{\mathrm{a}}$ & $3.67^{b, x}$ & 1.85 & $<0.05$ & $33.14^{\mathrm{a}}$ & $13.00^{\mathrm{b}, y}$ & 1.68 & $<0.05$ & $37.07^{\mathrm{a}}$ & $12.74^{b, y}$ & 1.24 & $<0.05$ \\
\hline FF GSH-Px (nmol/mL) & $83.56^{\mathrm{a}}$ & $55.29^{b, x}$ & 5.02 & $<0.05$ & 89.67 & $80.31^{y}$ & 4.96 & NS & 82.78 & $89.65^{y}$ & 6.01 & NS \\
\hline FF MDA $(\mathrm{nmol} / \mathrm{mL})$ & $2.37^{\mathrm{a}}$ & $4.14^{\mathrm{b}, \mathrm{x}}$ & 0.27 & $<0.05$ & 2.44 & $2.46^{y}$ & 0.26 & NS & 2.16 & $2.96^{y}$ & 0.21 & NS \\
\hline
\end{tabular}

a,b Values compared dietary levels within same follicle size; ${ }^{x, y}$ compared follicle sizes within the same dietary level. Different letters indicate ' $a$ ' significant difference $(P<0.05)$.

FF, follicular fluid; GSH-Px, glutathione peroxidase; MDA, maleic dialdehyde; SOD, superoxide dismutase; T-AOC, total antioxidant capacity. 
(Fenwick \& Hurst 2002). We suggested that short-term nutritional effects on granulosa cell apoptosis were possibly dependent on follicle development stage and follicle size, and that some protective mechanisms might predominate to remain dormant throughout the course of the reproductive lifespan, thus making them more resistant to atresia, but this finding should be investigated further.

Granulosa cell apoptosis results in follicular atresia due to insufficiency survival signals and physiologic or non-physiologic apoptotic signals (Johnson et al. 1996). The PI3K inhibitor increases the percentage of apoptotic granulosa cells treated with BMP7 in vitro, and this finding suggests that inactivated PI3K/PDK-1/ AKT signaling can significantly decrease the effect of BMP7 on granulosa cell apoptosis (Shimizu et al. 2011). PI3-kinase/AKT signaling serves as a functional survival pathway in ovaries by mediating IGF1-induced AKT phosphorylation and suggests that inactivation of this pathway causes granulosa cell apoptosis (Westfall et al. 2000). $\mathrm{H}_{2} \mathrm{O}_{2}$-induced OS leads to apoptosis of granulosa cells in vitro, and sphingosine-1-phosphate treatment can inhibit granulosa cell apoptosis by activating the PI3K/AKT pathway (Takuwa et al. 2012). These results provide an evidence for the role of the AKT signaling pathway in promoting granulosa cell survival. The anti-apoptotic protein AKT is normally activated by phosphorylation at Thr308 and Ser473, contributing to total AKT activity (Manning \& Cantley 2007). However, AKT Thr308 and Ser473 can be phosphorylated independently of each other (Alessi et al. 1996). Our present data show that enhanced granulosa cell apoptosis in the $\mathrm{R}$ group was accompanied with decreased phosphorylation at Ser473 but not with changes in the AKT phosphorylation at Thr308. This finding implies that AKT Ser473 might determine AKT specificity rather than its activity to trigger some relevant components of survival responses to nutrient limitations present in the granulosa cells in ovaries, depending on follicle size. In follicles $<2.5 \mathrm{~mm}$, the translation levels of phosphorylated and non-phosphorylated AKT were not significantly altered, and this observation indicates that the inhibitory effect of undernourishment on follicles $<2.5 \mathrm{~mm}$ was not related to the activity of the AKT signaling pathway in granulosa cells. In contrast, the increased expression of CYP19A1 responsible for estradiol secretion, the reduced expression level of CYP17A1 associated with androgen secretion and the inactivation of AKT signaling by the downregulated P-AKT473 in granulosa cells from follicles $\geq 2.5 \mathrm{~mm}$ were accompanied by the decreased insulin concentration in undernourishment. Therefore, the effect of feed restriction on ovarian follicle development and steroidogenesis through insulin signaling also appears to be dependent on the stage of development of follicles, which might result from the probable potential mechanism crosstalk with other functional signaling in the granulosa and theca cells of the ovulatory follicle.

Taken together, our results suggest that short-term feed restriction impairs folliculogenesis and extends the estrous cycle, alters the intra-follicular redox balance and thus enhances the apoptosis of granulosa cells from follicles $>2.5 \mathrm{~mm}$ in diameter under the role of AKT inactivation at Ser473 rather than at Thr308; however, the precise mechanisms of ROS-triggered AKT dephosphorylation remain to be investigated in further studies.

\section{Supplementary data}

This is linked to the online version of the paper at https://doi.org/10.1530/REP-17-0446.

\section{Declaration of interest}

The authors declare that there is neither conflict of interest that could be perceived as prejudicing the impartiality of the research reported nor any financial or other potential conflict of interest.

\section{Funding}

This work was supported by the China Agriculture Research System (Grant number: CARS-38), the Key Research and Development Plan of Jiangsu Province (Grant number: BE2015362) and the New Agricultural Project of JiangSu Province (Grant number: SXGC2016141).

\section{Acknowledgements}

The authors wish to thank YiXuan Fan for her help in the collection of the experimental materials, and Shijia Ying, Li Meng and Mohmed El-samahy for their helps in manuscript writing improvement and design of the statistical analysis.

\section{References}

Alessi DR, Andjelkovic M, Caudwell B, Cron P, Morrice N, Cohen P \&
Hemmings BA 1996 Mechanism of activation of protein kinase B by
insulin and IGF-1. EMBO Journal $\mathbf{1 5} 6541-6551$.
Amer HZ, Ellamie AM \& Askar AR 2013 Effect of feed restriction on
oxidative stress indices and lipid profile in dry Barki ewes. Egypt Journal
of Basic Applied Physiology $\mathbf{1 2} 413-425$.
Arakawa SM, lyo M, Ohkawa R, Kambegawa A, Okinaga S \& Arai K
1989 Steroid hormone receptors in the uterus and ovary of immature
rats treated with gonadotropins. Endocrinologia Japonica $\mathbf{3 6} 219-228$.
(https://doi.org/10.1507/endocrj1954.36.219)
Asselin E, Wang Y \& Tsang BK 2001 X-linked inhibitor of apoptosis protein
activates the phosphatidylinositol 3-kinase/Akt pathway in rat granulosa
cells during follicular development. Endocrinology $\mathbf{1 4 2} 2451-2457$.
(https://doi.org/10.1210/endo.142.6.8080)
Basini G, Simona B, Santini SE \& Grasselli F 2008 Reactive oxygen species
and anti-oxidant defences in swine follicular fluids. Reproduction Fertility
and Development 20 269-274. (https://doi.org/10.1071/rd07147) 
Bruynsteen L, Janssens GP, Harris PA, Duchateau L, Valle E, Odetti P, Vandevelde K, Buyse J \& Hesta M 2014 Changes in oxidative stress in response to different levels of energy restriction in obese ponies. British Journal of Nutrition 112 1-10. (https://doi.org/10.1017/ S0007114514001974)

Cecconi S, Mauro A, Cellini V \& Patacchiola F 2012 The role of Akt signalling in the mammalian ovary. International Journal of Developmental Biology 56 809-817. (https://doi.org/10.1387/ijdb.120146sc)

Chen W, Su H, Xu Y, Bao T \& Zheng X 2016 Protective effect of wild raspberry (Rubus hirsutus Thunb.) extract against acrylamide-induced oxidative damage is potentiated after simulated gastrointestinal digestion. Food Chemistry 196 943-952. (https://doi.org/10.1016/j. foodchem.2015.10.024)

Cheng JQ, Altomare DA, Klein MA, Lee WC, Kruh GD, Lissy NA \& Testa JR 1997 Transforming activity and mitosis-related expression of the AKT2 oncogene: evidence suggesting a link between cell cycle regulation and oncogenesis. Oncogene 14 2793-2801. (https://doi.org/10.1038/ sj.onc.1201121)

Ding J, Takano T, Gao S, Han W, Noda C, Yanagi S \& Yamamura H 2000 Syk is required for the activation of Akt survival pathway in B cells exposed to oxidative stress. Journal of Biological Chemistry 275 30873-30877. (https://doi.org/10.1074/jbc.M004813200)

Downs SM \& Utecht AM 1999 Metabolism of radiolabeled glucose by mouse oocytes and oocyte-cumulus cell complexes. Biology of Reproduction 60 1446-1452. (https://doi.org/10.1095/biolreprod60.6.1446)

Fattman CL, Schaefer LM \& Oury TD 2003 Extracellular superoxide dismutase in biology and medicine. Free Radical Biology and Medicine 35 236-256. (https://doi.org/10.1016/s0891-5849(03)00275-2)

Fenwick MA \& Hurst PR 2002 Immunohistochemical localization of active caspase-3 in the mouse ovary: growth and atresia of small follicles. Reproduction 124 659-665. (https://doi.org/10.1530/rep.0.1240659)

França MR, Mesquita FS, Lopes E, Pugliesi G, Van HV, Chiaratti MR, Membrive CB, Papa PC \& Binelli M 2015 Modulation of periovulatory endocrine profiles in beef cows: consequences for endometrial glucose transporters and uterine fluid glucose levels. Domestic Animal Endocrinology $50 \quad 83-90 . \quad$ (https://doi.org/10.1016/j. domaniend.2014.09.005)

Gallet C, Dupont J, Campbell BK, Monniaux D, Guillaume D \& Scaramuzzi RJ 2011 The infusion of glucose in ewes during the luteal phase increases the number of follicles but reduces oestradiol production and some correlates of metabolic function in the large follicles. Animal Reproduction Science 127 154-163. (https://doi.org/10.1016/j. anireprosci.2011.07.017)

Goto M, Iwase A, Ando H, Kurotsuchi S, Harata T \& Kikkawa F 2007 PTEN and Akt expression during growth of human ovarian follicles. Journal of Assisted Reproduction and Genetics 24 541-546. (https://doi. org/10.1007/s10815-007-9156-3)

Hoyer PB, Devine PJ, Hu X, Thompson KE \& Sipes IG 2001 Ovarian toxicity of 4-vinylcyclohexene diepoxide: a mechanistic model. Toxicologic Pathology 29 91-99. (https://doi.org/10.1080/019262301301418892)

Johnson AL, Bridgham JT, Witty JP \& Tilly JL 1996 Susceptibility of avian ovarian granulosa cells to apoptosis is dependent upon stage of follicle development and is related to endogenous levels of bcl-xlong gene expression. Endocrinology 137 2059-2066. (https://doi.org/10.1210/ endo.137.5.8612548)

Johnson BW \& Boise LH 1999 Bcl-2 and caspase inhibition cooperate to inhibit tumor necrosis factor-alpha-induced cell death in a Bcl-2 cleavage-independent fashion. Journal of Biological Chemistry 274 18552-18558. (https://doi.org/10.1074/jbc.274.26.18552)

Johnson F \& Giulivi C 2005 Superoxide dismutases and their impact upon human health. Molecular Aspects of Medicine 26 340-352. (https://doi. org/10.1016/j.mam.2005.07.006)

Jolly PD, Tisdall DJ, Heath DA, Lun S \& Mcnatty KP 1994 Apoptosis in bovine granulosa cells in relation to steroid synthesis, cyclic adenosine $3^{\prime}, 5^{\prime}$-monophosphate response to follicle-stimulating hormone and luteinizing hormone, and follicular atresia. Biology of Reproduction $\mathbf{5 1}$ 934-944. (https://doi.org/10.1095/biolreprod51.5.934)

Hughes FM Jr \& Gorospe WC 1991 Biochemical identification of apoptosis (programmed cell death) in granulosa cells: evidence for a potential mechanism underlying follicular atresia. Endocrinology 129 2415-2422. (https://doi.org/10.1210/endo-129-5-2415)
Kaipia A \& Hsueh AJ 1997 Regulation of ovarian follicle atresia. Annual Review of Physiology 59 349-363. (https://doi.org/10.1146/annurev. physiol.59.1.349)

Killeen ID 1982 Effects of fasting ewes before mating on their reproductive performance. Theriogenology 17 433-435. (https://doi. org/10.1016/0093-691X(82)90024-3)

Lahair MM, Howe CJ, Rodriguezmora O, Mccubrey JA \& Franklin RA 2006 Molecular pathways leading to oxidative stress-induced phosphorylation of Akt. Antioxidants and Redox Signaling 8 1749-1756. (https://doi. org/10.1089/ars.2006.8.1749)

Lindsay DR 1976 The usefulness to the animal producer of research findings in nutrition on reproduction (conference paper). Spine 32 1896-1901.

Manning BD \& Cantley LC 2007 AKT/PKB signaling: navigating downstream. Cell 129 1261-1274. (https://doi.org/10.1016/j.cell.2007.06.009)

Matsuda-Minehata F, Goto Y, Inoue N \& Manabe N 2005 Changes in expression of anti-apoptotic protein, cflip, in granulosa cells during follicular atresia in porcine ovaries. Molecular Reproduction and Development 72 145-151. (https://doi.org/10.1002/mrd.20349)

Meng C, Shi F, Zhou Z, Huang R, Liu G, Watanabe G \& Taya K 2007 Cellular localization of inhibin alpha-subunit, PKB/Akt and FoxO3a proteins in the ovaries of minipigs. Journal of Reproduction and Development $\mathbf{5 3}$ 229-236. (https://doi.org/10.1262/jrd.18078)

Muñozgutiérrez M, Blache D, Martin GB \& Scaramuzzi RJ 2002 Folliculogenesis and ovarian expression of mRNA encoding aromatase in anoestrous sheep after 5 days of glucose or glucosamine infusion or supplementary lupin feeding. Reproduction 124 721-731. (https://doi. org/10.1530/rep.0.1240721)

Munoz-Gutiérrez M, Blache D, Martin GB \& Scaramuzzi RJ 2004 Ovarian follicular expression of mRNA encoding the type I IGF receptor and IGF-binding protein-2 in sheep following five days of nutritional supplementation with glucose, glucosamine or lupins. Reproduction 128 747-756. (https://doi.org/10.1530/rep.1.00439)

Murdoch WJ 1995 Programmed cell death in preovulatory ovine follicles. Biology of Reproduction 53 8-12. (https://doi.org/10.1095/ biolreprod53.1.8)

Nogueira V, Park Y, Chen CC, Xu PZ, Chen ML, Tonic I, Unterman T \& Hay N 2008 Akt determines replicative senescence and oxidative or oncogenic premature senescence and sensitizes cells to oxidative apoptosis. Cancer Cell 14 458-470. (https://doi.org/10.1016/j. ccr.2008.11.003)

Ohkawa H, Ohishi N \& Yagi K 1979 Assay for lipid peroxides in animal tissues by thiobarbituric acid reaction. Analytical Biochemistry 95 351-358. (https://doi.org/10.1016/0003-2697(79)90738-3)

Ostrowska M, Jarczak J \& Zwierzchowski L 2015 Glucose transporters in cattle - a review. Animal Science Papers and Reports 33 191-212.

Reddy P, Shen L, Ren C, Boman K, Lundin E, Ottander U, Lindgren P, Liu YX, Sun QY \& Liu K 2005 Activation of Akt (PKB) and suppression of FKHRL1 in mouse and rat oocytes by stem cell factor during follicular activation and development. Developmental Biology 281 160-170. (https://doi.org/10.1016/j.ydbio.2005.02.013)

Rhind SM, Leslie ID, Gunn RG \& Doney JM 1985 Plasma FSH, LH, prolactin and progesterone profiles of Cheviot ewes with different levels of intake before and after mating, and associated effects on reproductive performance. Animal Reproduction Science 8 301-313. (https://doi. org/10.1016/0378-4320(85)90046-6)

Scaramuzzi RJ, Campbell BK, Downing JA, Kendall NR, Khalid M, MuñozGutiérrez M \& Somchit A 2006 A review of the effects of supplementary nutrition in the ewe on the concentrations of reproductive and metabolic hormones and the mechanisms that regulate folliculogenesis and ovulation rate. Reproduction Nutrition Development 46 339-354. (https://doi.org/10.1051/rnd:2006016)

Scaramuzzi RJ, Zouaïdi N, Menassol JB \& Dupont J 2015 The effects of intravenous, glucose versus saline on ovarian follicles and their levels of some mediators of insulin signalling. Reproductive Biology of Endocrinology 13 1-14. (https://doi.org/10.1186/1477-7827-13-1)

Shimizu T, Kayamori T, Murayama C \& Miyamoto A 2011 Bone morphogenetic protein (BMP)-4 and BMP-7 suppress granulosa cell apoptosis via different pathways: BMP-4 via PI3K/PDK-1/Akt and BMP-7 via PI3K/PDK-1/PKC. Biochemical and Biophysical Research Communications 417 869-873. (https://doi.org/10.1016/j. bbrc.2011.12.064) 
Somchit A, Campbell BK, Khalid M, Kendall NR \& Scaramuzzi RJ 2007 The effect of short-term nutritional supplementation of ewes with lupin grain (Lupinus luteus), during the luteal phase of the estrous cycle on the number of ovarian follicles and the concentrations of hormones and glucose in plasma and follicular fluid. Theriogenology 68 1037-1046. (https://doi.org/10.1016/j.theriogenology.2007.08.001)

Sugimoto $M$, Manabe N, Kimura $\mathrm{Y}$, Myoumoto A, Imai $\mathrm{Y}$, Ohno H \& Miyamoto H 1998 Ultrastructural changes in granulosa cells in porcine antral follicles undergoing atresia indicate apoptotic cell death. Journal of Reproduction and Development 44 7-14. (https://doi.org/10.1262/jrd.44.7)

Takuwa Y, Okamoto Y, Yoshioka K \& Takuwa N 2012 Sphingosine-1phosphate signaling in physiology and diseases. Biofactors 38 329-337. (https://doi.org/10.1002/biof.1030)

Tilly JL \& Tilly KI 1995 Inhibitors of oxidative stress mimic the ability of follicle-stimulating hormone to suppress apoptosis in cultured rat ovarian follicles. Endocrinology 136 242-252. (https://doi.org/10.1210/ endo.136.1.7828537

Tsaiturton M \& Luderer U 2006 Opposing effects of glutathione depletion and follicle-stimulating hormone on reactive oxygen species and apoptosis in cultured preovulatory rat follicles. Endocrinology 147 1224-1236. (https://doi.org/10.1210/en.2005-1281)

Viñoles C, Forsberg M, Martin GB, Cajarville C, Repetto J \& Meikle A 2005 Short-term nutritional supplementation of ewes in low body condition affects follicle development due to an increase in glucose and metabolic hormones. Reproduction 129 299-309. (https://doi. org/10.1530/rep.1.00536)

Viñoles Gil C 2003 Effect of nutrition of follicle development and ovulation rate in the ewe. Thesis, Doctoral. Swedish University of Agricultural Sciences.

Waddington D, Perry MM, Gilbert AB \& Hardie MA 1985 Follicular growth and atresia in the ovaries of hens (Gallus domesticus) with diminished egg production rate. Journal of Reproduction and Fertility 74 399-405. (https://doi.org/10.1530/jrf.0.0740399)

Wang X, Mccullough KD, Franke TF \& Holbrook NJ 2000 Epidermal growth factor receptor-dependent Akt activation by oxidative stress enhances cell survival. Journal of Biological Chemistry 275 14624-14631. (https:// doi.org/10.1074/jbc.275.19.14624)
Westfall SD, Hendry IR, Obholz KL, Rueda BR \& Davis JS 2000 Putative role of the phosphatidylinositol 3-kinase-Akt signaling pathway in the survival of granulosa cells. Endocrine 12 315-321. (https://doi. org/10.1385/ENDO:12:3:315)

Williams SA, Blache D, Martin GB, Foot R, Blackberry MA \& Scaramuzzi RJ 2001 Effect of nutritional supplementation on quantities of glucose transporters 1 and 4 in sheep granulosa and theca cells. Reproduction 122 947-956. (https://doi.org/10.1530/rep.0.1220947)

Yakubu SI, Yakasai IA \& Musa A 2011 Spectrofluorimetric assay method for glutathione and glutathione transferase using monobromobimane. Journal of Basic and Clinical Pharmacy 2 151-158.

Yikilmaz E, Rodgers DW \& Miller AF 2006 The crucial importance of chemistry in the structure-function link: manipulating hydrogen bonding in iron-containing superoxide dismutase. Biochemistry 45 1151-1161. (https://doi.org/10.1021/bi051495d)

Ying S, Wang Z, Wang C, Nie H, He D, Jia R, Wu Y, Wan Y, Zhou Z \& Yan Y 2011 Effect of different levels of short-term feed intake on folliculogenesis and follicular fluid and plasma concentrations of lactate dehydrogenase, glucose, and hormones in Hu sheep during the luteal phase. Reproduction 142 699-710. (https://doi.org/10.1530/REP-11-0229)

Zhan XA, Wang M, Zhao RQ, Li WF \& Xu ZR 2007 Effects of different selenium source on selenium distribution, loin quality and antioxidant status in finishing pigs. Animal Feed Science and Technology 132 202-211. (https://doi.org/10.1016/j.anifeedsci.2006.03.020)

Zhang JQ, Ming S, Zhu CC, Yu FX, Liu ZQ, Nazim A, Sun SC, Li K \& Liu HL 2014 3-Nitropropionic acid induces ovarian oxidative stress and impairs follicle in mouse. PLOS ONE 9 1-12. (https://doi.org/10.1371/journal. pone.0116339)

Received 21 July 2017

First decision 14 August 2017

Revised manuscript received 12 October 2017

Accepted 23 October 2017 